\title{
Phylogenetic analysis of Newcastle disease viruses isolated from wild birds in the Poyang Lake region of China
}

\author{
Shengtao $\mathrm{FAN}^{1,2)}$, Tiecheng $\mathrm{WANG}^{2}$, Xiaolong $\mathrm{GAO}^{3)}$, Ying $\mathrm{YING}^{4}$ ), Xue $\mathrm{LI}^{2)}$, Yongcheng $\mathrm{LI}^{5)}$, Yuanguo $\mathrm{LI}^{2}$, \\ Jinzhu $\mathrm{MA}^{2)}$, Heting $\mathrm{SUN}^{5)}$, Dong $\mathrm{CHU}^{5)}$, $\mathrm{Yu} \mathrm{XU}^{5)}$, Songtao $\mathrm{YANG}^{2)}$, Qihan $\mathrm{LI}^{1)}$, Yuwei $\mathrm{GAO}^{2) *}$ and Xianzhu XIA ${ }^{2) *}$ \\ 1) Institute of Medical Biology, Chinese Academy of Medical Sciences \& Peking Union Medical College, Kunming 650118, PR China \\ ${ }^{2)}$ Key Laboratory of Jilin Province for Zoonosis Prevention and Control, Institute of Military Veterinary, Academy of Military Medical \\ Sciences, No. 666, Liuying Xilu, Jingyue Economic Development Zone, Changchun 130122, PR China \\ ${ }^{3}$ State Key Laboratory of Veterinary Biotechnology, Harbin Veterinary Research Institute, Chinese Academy of Agricultural Sciences, \\ Harbin 150001, PR China \\ ${ }^{4)}$ College of Animal Science and Technology, Jilin Agricultural University, Changchun 130118, PR China \\ ${ }^{5)}$ General Station for surveillance of wildlife Diseases \& Wildlife Borne Disease, State Forestry Administration, Shenyang 110086, PR \\ China
}

(Received 14 February 2014/Accepted 21 March 2015/Published online in J-STAGE 3 April 2015)

ABSTRACT. Newcastle disease virus (NDV) causes a highly contagious viral disease in poultry and wild birds, and it can cause significant economic loss worldwide. Eight viral strains were isolated by inoculating embryonated chicken eggs from the Poyang Lake region of China with swab samples. All eight of the NDV isolates were identified as class I genotype 3 strains, but they diverged notablely from class II viruses. Further analysis revealed that all eight NDV isolates were lentogenic strains containing the ${ }^{112} \mathrm{ERQER} \downarrow \mathrm{L}^{117}$ motif at the F protein cleavage site. The strains were highly identical and were more species specific (chicken and waterfowl) than site specific (Nanchang and Duchang regions). The close phylogenetic proximity of these isolates indicates that viral transmission may happen between poultry and wild birds. Our study demonstrates that lentogenic class I NDVs exist in clinically healthy wild waterfowl and poultry within the Poyang Lake region. Active surveillance of these viruses to determine their evolution and origin is one of the most realistic strategies for preventing and controlling NDV outbreaks.

KEY WORDS: genotype, Newcastle disease virus, phylogenetic analysis, Poyang Lake

doi: 10.1292/jvms.14-0080; J. Vet. Med. Sci. 77(9): 1143-1149, 2015

Newcastle disease virus (NDV) is a member of the Avulavirus genus in the Paramyxoviridae family and the Mononegavirales order [6]. It causes a highly contagious viral disease in wild birds worldwide, and it can cause severe economic losses in the poultry industry $[1,9,23]$. This non segmented and negative single-stranded RNA virus has a genome of 15,186 to 15,198 nucleotides encoding six major proteins: phosphoprotein $(\mathrm{P})$, nucleoprotein (NP), hemagglutinin-neuraminidase $(\mathrm{HN})$, fusion $(\mathrm{F})$, matrix $(\mathrm{M})$ and RNA polymerase (L) [4]. As the 2 surface glycoproteins, HN and $\mathrm{F}$ are the major protective antigens and viral neutralization antigens. The $\mathrm{F}$ protein cleavage site sequence is considered to be the major molecular determinant of NDV virulence [11]. Apart from the F protein cleavage site, the HN protein also contributes to NDV virulence [7]. Phylogenetically, NDVs are classified into 2 major groups, class I and class

*Correspondence to: Xia, X. or Gao,Y., Key Laboratory of Jilin Province for Zoonosis Prevention and Control, Institute of Military Veterinary, Academy of Military Medical Sciences, No. 666, Liuying Xilu, Jingyue Economic Development Zone, Changchun 130122, PR China. e-mail: xiaxzh@cae.cn (XIA), gaoyuwei@, gmail.com (GAO)

(C2015 The Japanese Society of Veterinary Science

This is an open-access article distributed under the terms of the Creative Commons Attribution Non-Commercial No Derivatives (by-nc-nd) License $<$ http://creativecommons.org/licenses/by-nc-nd/3.0/>.
II $[5,12]$. Class I viruses encompass at least nine genotypes [17]; however, in a recent study, these have been condensed into a single genotype [8]. These viruses are almost exclusively lentogenic strains and are found in waterfowl and at live bird markets [26]. Class II viruses are generally more virulent and are primarily responsible for the infections observed in pet birds and poultry [3] and are divided into different genotypes $[5,22,24]$. Some studies have indicated that wild birds and waterfowl may play a significant role in the evolution of NDV [16, 18, 21]. However, epidemiological and virological information about NDVs circulation in wild birds and waterfowl is still known little, and their potential to cause disease in domestic poultry is extraordinary limited. Wild aquatic birds are thought to be the natural reservoirs of NDVs of both classes, but they predominantly harbor lentogenic strains $[1,18]$. However, some lentogenic strains have the potential to become velogenic after transmission and circulation within poultry populations [27].

Poyang Lake is the largest freshwater lake in China and is an important breeding site for many migratory birds. Thus, there are opportunities for the transmission of viruses among waterfowl, which increases the risk of poultry being exposed to these strains. Here, we report our NDV screening results from wild waterfowl in the Nanchang, Jiujiang and Duchang sites near Poyang Lake. The NDV isolates in this study were characterized by sequencing to determine the genotypes and pathotypes involved. 


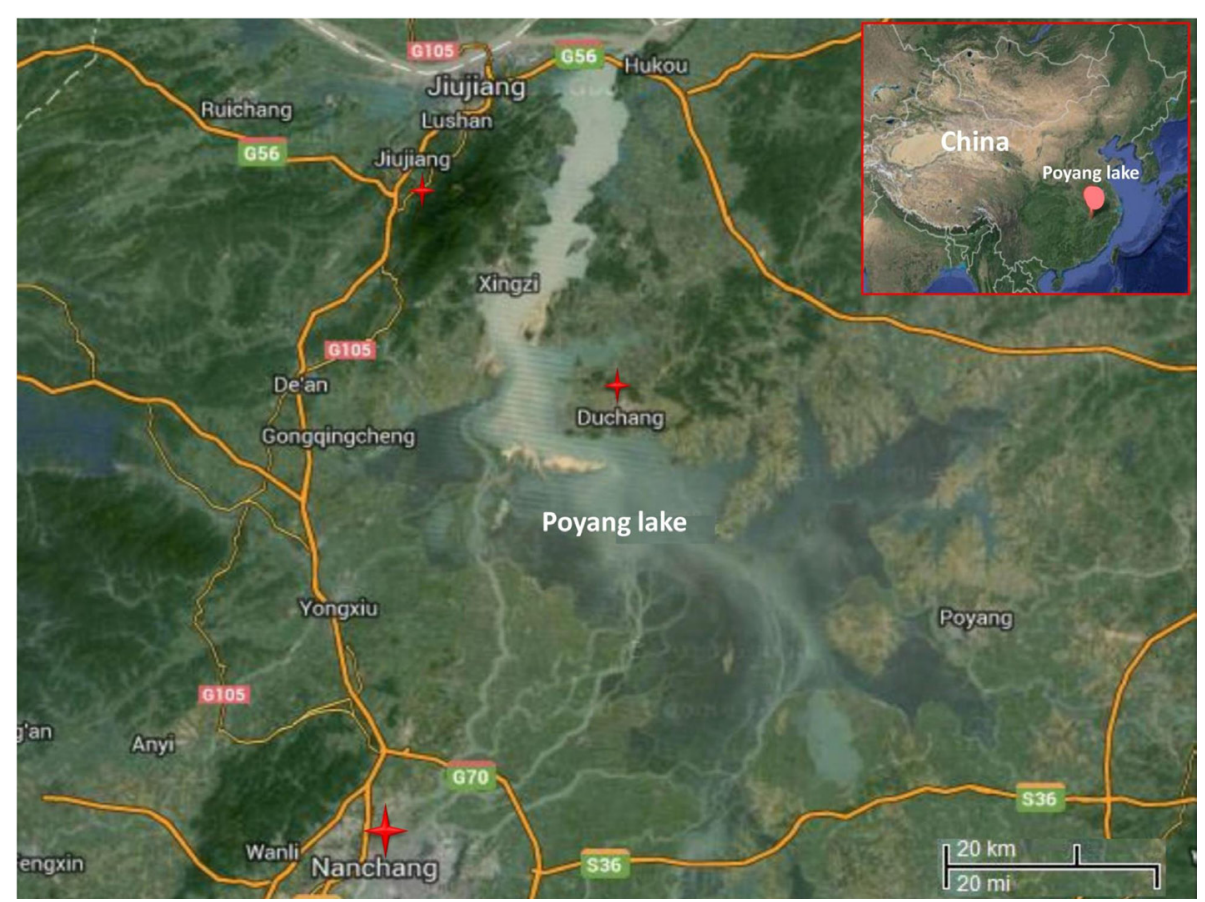

Fig. 1. Distribution of collected samples from the Poyang Lake in China. The isolated NDVs are indicated by red "stars".

A total of 284 swab samples were collected from three sites in Jiangxi province (Fig. 1) from March to July of 2013. The collected samples were inoculated into 9-day-old embryonated specific-pathogen-free (SPF) chicken eggs and incubated for $48 \mathrm{hr}$ at $37^{\circ} \mathrm{C}$. The presence virus of allantoic fluid was confirmed using the hemagglutination (HA) assay [1] and hemagglutination inhibition (HI) assay with NDVspecific polyclonal antiserum. Of these, eight samples from three bird species (Anas poecilorhyncha, Anser cygnoides and chicken) contained NDV based on HI analysis. The total isolation rate was $2.8 \%$ (4/143 in Nanchang City, 4/119 in Duchang County and 0/22 in Jiujiang County) (Table 2).

To evaluate the pathogenic potential of the isolated viruses, standard assay methods were used to determine the intracerebral pathogenicity index (ICPI) in 1-day-old SPF chicks and the mean death time (MDT) in 9-day-old embryonated SPF chicken eggs [14]. The MDT values of two strains isolated from chicken were $96 \mathrm{hr}$, however, the MDT values of six strains isolated from wild bird were more than $120 \mathrm{hr}$. The ICPI values of all 8 strains were 0 , indicating that they were all lentogenic. It has been proven that cleavage of the NDV F protein is a major determinant of NDV virulence. The amino acid sequence of the $\mathrm{F}$ protein cleavage site is ${ }^{112} \mathrm{R} / \mathrm{K}-\mathrm{R}-\mathrm{Q}-\mathrm{R} / \mathrm{K}-\mathrm{R} \downarrow \mathrm{F}^{117}$ for velogenic and mesogenic strains; however, the lentogenic strains $\mathrm{F}$ cleavage site is ${ }^{112} \mathrm{G} / \mathrm{E}-\mathrm{K} / \mathrm{R}-\mathrm{Q}-\mathrm{G} / \mathrm{E}-\mathrm{R} \downarrow \mathrm{L}^{117}[7,17]$. In addition, the HN protein also contributes to NDV virulence [7]. To gain a better understanding of NDV virulence in the Poyang Lake samples, the complete $\mathrm{F}$ and $\mathrm{HN}$ sequences were recovered from the eight isolates. All eight isolates were identified as lentogenic strains containing the ${ }^{112} \mathrm{ERQER} \downarrow \mathrm{L}^{117}$ motif at the F protein cleavage site.

The coding regions of $\mathrm{F}$ and $\mathrm{HN}$ genes isolated were used for analysis. Prediction of amino acid sequences and aligment of sequences were performed using MegAlign in the Lasergene V 7.1. The fusion gene was amplified using the following primers: forward primer (47-69): 5'-ATGAATCCCAAGCCCTCTACCAG- ${ }^{\prime}$ and reverse primer (1686-1708):5'-TTACATCTTTGTCGTTGCTCTCA-3'. The HN gene was amplified as described previously [15]. The PCR products were sequenced as described previously [10]. Based on different genotypes, all eight isolates shared unique substitutions $\left(\mathrm{N}^{2}\right.$-for-D, $\mathrm{T}^{93}$-for- $\mathrm{A}, \mathrm{D}^{104}$-for-E, $\mathrm{H}^{337}$ for- $\mathrm{Y}$ and $\mathrm{N}^{489}$-for-D) in the $\mathrm{F}$ protein sequences compared with other class I viruses (Table 3, other aligned reference sequences are shown in Table S1). Nineteen specific residue substitutions were found in the Class I genotype 3 viruses $\mathrm{HN}$ protein sequences compared with other class I viruses (Table 4, other aligned reference sequences are shown in Table S2), and all eight isolates showed unique $\mathrm{T}^{43}$-for-A, $\mathrm{S}^{60}$-for-P/T and $\mathrm{S}^{577}$-for-A substitutions compared with other class I genotype 3 viruses. A comparison of the $\mathrm{HN}$ protein sequences between chicken strains (AB859010 and AB859008) and other class I genotype 3 viruses (including 6 wild bird strains isolated) was performed, and the following substitutions $\mathrm{E}^{293}$-for-G, $\mathrm{I}^{580}$-for- $\mathrm{T}$ and $\mathrm{I}^{590}$-for-V were found in chicken strains.

The amino acid sequences of the F protein were compared for the 8 isolates, and the sequence identities ranged from 98.5 to $99.5 \%$. The amino acid identities for the 8 isolates 
Table 1. Details of F and HN genes used in this study

\begin{tabular}{|c|c|c|c|c|c|c|}
\hline $\begin{array}{c}\text { GenBank } \\
\text { accession number }\end{array}$ & Isolate name & $\begin{array}{l}\text { Fusion gene cleavage } \\
\text { site }(112-117)\end{array}$ & Class & Genotype & HN gene & Country \\
\hline EF564833 & Canada goose/US $(\mathrm{OH}) / 87-78 / 1987$ & ERQER $\downarrow L$ & I & 1 & - & USA \\
\hline HQ008337 & Duck/China/JS10/2010 & ERQER $\downarrow L$ & I & 2 & - & China \\
\hline KF055275 & Duck/China/Ch/D10/2009 & ERQER $\downarrow L$ & I & 2 & - & China \\
\hline JF893453 & Duck/China/JX07/2007 & ERQER $\downarrow L$ & I & 2 & - & China \\
\hline EU493454 & Pochard/Finland/13193/2006 & ERQER $\downarrow L$ & I & 2 & - & Finland \\
\hline HQ398788 & Duck/China/NDV09-014/2009 & ERQER $\downarrow L$ & I & 3 & - & China \\
\hline HQ398789 & Duck/China/NDV09-015/2009 & ERQER $\downarrow L$ & I & 3 & - & China \\
\hline HQ398790 & Duck/China/NDV09-016/2009 & ERQER $\downarrow L$ & I & 3 & - & China \\
\hline FJ597594 & Duck/China/D_ZJ_20_05/2005 & EQQER $\downarrow L$ & I & 3 & - & China \\
\hline FJ597597 & Duck/China/ D_SD_- 29 _e5/2005 & EQQER $\downarrow L$ & I & 3 & - & China \\
\hline JN688865 & Goose/Jiangsu/ G-JS-09-08/2009 & EQQGR $\downarrow L$ & I & 3 & - & China \\
\hline FJ597588 & Duck/China/D_JS_17_05/2005 & EQQER $\downarrow L$ & I & 3 & - & China \\
\hline FJ597600 & Duck/China/D_ZJ_30_05/2005 & EQQER $\downarrow L$ & I & 3 & - & China \\
\hline EF564813 & Green winged teal/US (AK)/176/1998 & ERQER $\downarrow L$ & I & 4 & - & USA \\
\hline EF564825 & Mallard/US (MD)/02-336/2002 & ERQER $\downarrow L$ & I & 4 & - & USA \\
\hline AY626267 & Duck/U.S./154979-1/2001 & ERQER $\downarrow L$ & I & 5 & - & USA \\
\hline AY626266 & Duck/U.S./119535-1/2001 & ERQER $\downarrow L$ & I & 6 & - & USA \\
\hline AY626268 & Chicken/U.S./101250-2/2001 & ERQER $\downarrow L$ & I & 6 & - & USA \\
\hline EF564819 & Red knot/US (DE)/2026/2000 & ERQER $\downarrow L$ & I & 7 & - & USA \\
\hline EF564820 & Mallard/US (MD)/04-125/2004 & $\mathrm{ERQER} \downarrow \mathrm{L}$ & I & 7 & - & USA \\
\hline JN941987 & Northern Pintail/Idaho/19663-2/2009 & ERQER $\downarrow L$ & I & 7 & - & USA \\
\hline EF564815 & Dunlin/US (DE)/A100-2093/2000 & ERQER $\downarrow L$ & I & 8 & - & USA \\
\hline EF564831 & Ruddy turnstone/US (DE)/401/2004 & ERQER $\downarrow L$ & I & 8 & - & USA \\
\hline EF565029 & Blue winged teal/US (TX)/02-11/2002 & ERQER $\downarrow L$ & I & 9 & - & USA \\
\hline AB858995* & Anser cygnoides/Duchang/J17-13-F/2013 & ERQER $\downarrow L$ & I & 3 & - & China \\
\hline AB858996 & Anas poecilorhyncha/Nanchang/J72-13-F/2013 & ERQER $\downarrow L$ & I & 3 & - & China \\
\hline AB859001 & Anas poecilorhyncha/Nanchang/J70-13-F/2013 & ERQER $\downarrow L$ & I & 3 & - & China \\
\hline AB859002 & Chicken/Nanchang/J2-13-F/2013 & ERQER $\downarrow L$ & I & 3 & - & China \\
\hline AB858997 & Anser cygnoides/Duchang/J55-13-F/2013 & ERQER $\downarrow L$ & I & 3 & - & China \\
\hline AB858998 & Anas poecilorhyncha/Duchang/J77-13-F/2013 & ERQER $\downarrow L$ & I & 3 & - & China \\
\hline AB858999 & Anas poecilorhyncha/Duchang/J80-13-F/2013 & ERQER $\downarrow L$ & I & 3 & - & China \\
\hline AB859000 & Chicken/Nanchang/J36-13-F/2013 & ERQER $\downarrow L$ & I & 3 & - & China \\
\hline FJ597604 & Duck/China/D/AH/6/04/2004 & EKQGR $\downarrow L$ & II & $\mathrm{Ib}$ & - & China \\
\hline FJ597609 & Duck/China/D/JS/51/05/2005 & GKQGR $\downarrow V$ & II & $\mathrm{Ib}$ & - & China \\
\hline DQ195265 & USA/LaSota/2005 & GRQGR $\downarrow L$ & II & II & - & USA \\
\hline JN618349 & Chicken/China/JS-3-05-Ch/2005 & $\mathrm{RRQKR} \downarrow \mathrm{F}$ & II & VII & - & China \\
\hline DQ659677 & China/NA-1/2006 & $\mathrm{RRQKR} \downarrow \mathrm{F}$ & II & VII & - & China \\
\hline NC 005036 & Goose/China/SF02/2002 & $\mathrm{RRQKR} \downarrow \mathrm{F}$ & II & VII & - & China \\
\hline AB859003 & Anser cygnoides/Duchang/J17-13-HN/2013 & - & I & 3 & $\mathrm{HN}$ & China \\
\hline AB859004 & Anas poecilorhyncha/Nanchang/J72-13-HN/2013 & - & I & 3 & $\mathrm{HN}$ & China \\
\hline AB859005 & Anser cygnoides/Duchang/J55-13-HN/2013 & - & I & 3 & $\mathrm{HN}$ & China \\
\hline AB859006 & Anas poecilorhyncha/Duchang/J77-13-HN/2013 & - & I & 3 & $\mathrm{HN}$ & China \\
\hline AB859007 & Anas poecilorhyncha/Duchang/J80-13-HN/2013 & - & I & 3 & $\mathrm{HN}$ & China \\
\hline AB859008 & Chicken/Nanchang/J36-13-HN/2013 & - & I & 3 & $\mathrm{HN}$ & China \\
\hline AB859009 & Anas poecilorhyncha/Nanchang/J70-13-HN/2013 & - & I & 3 & $\mathrm{HN}$ & China \\
\hline AB859010 & Chicken/Nanchang/J2-13-HN/2013 & - & I & 3 & $\mathrm{HN}$ & China \\
\hline HQ997403 & Chicken/China/NDV10-059/2010 & - & I & 3 & $\mathrm{HN}$ & China \\
\hline HQ997404 & Chicken/China/NDV10-060/2010 & - & I & 3 & $\mathrm{HN}$ & China \\
\hline HQ997405 & Chicken/China/NDV10-061/2010 & - & I & 3 & $\mathrm{HN}$ & China \\
\hline HQ997406 & Chicken/China/NDV10-062/2010 & - & I & 3 & $\mathrm{HN}$ & China \\
\hline HQ997410 & Chicken/China/NDV10-069/2010 & - & I & 3 & $\mathrm{HN}$ & China \\
\hline HQ398840 & Chicken/China/NDV09-043/2009 & - & I & 3 & $\mathrm{HN}$ & China \\
\hline HQ398841 & Chicken/China/NDV09-044/2009 & - & I & 3 & $\mathrm{HN}$ & China \\
\hline HQ398846 & Chicken/China/NDV09-051/2009 & - & I & 3 & $\mathrm{HN}$ & China \\
\hline HQ398847 & Chicken/China/NDV09-052/2009 & - & I & 3 & $\mathrm{HN}$ & China \\
\hline HQ398848 & Chicken/China/NDV09-053/2009 & - & I & 3 & $\mathrm{HN}$ & China \\
\hline HQ398849 & Chicken/China/NDV09-054/2009 & - & I & 3 & $\mathrm{HN}$ & China \\
\hline
\end{tabular}

“*”The bold indicated NDV strains isolated in this study 
Table 2. Samples collected and NDV strains isolated in this study

\begin{tabular}{llcccc}
\hline \multirow{2}{*}{ Location } & \multirow{2}{*}{ Species } & \multicolumn{2}{c}{ No. of samples } & \multirow{2}{*}{ No. of positive (\%) } & \multirow{2}{*}{ Class (genotypes) } \\
\cline { 3 - 5 } & & Oral & Cloacal & & I (3) \\
\hline \multirow{2}{*}{ Nanchang } & Anas poecilorhyncha & 100 & 0 & $2(2.0)$ & I (3) \\
& Chicken & 0 & 43 & $2(4.7)$ & \\
Jiujiang & Anser cygnoides & 22 & 0 & 0 & I (3) \\
Duchang & Anas poecilorhyncha & 43 & 25 & $2(2.9)$ & I (3) \\
& Anser cygnoides & 37 & 14 & $2(3.9)$ & \\
Total & & 202 & 82 & $8(2.8)$ & \\
\hline
\end{tabular}

Table 3. Specific amino acids substitution in the fusion protein sequences in this study

\begin{tabular}{|c|c|c|c|c|c|c|c|}
\hline \multirow{2}{*}{$\begin{array}{c}\text { GenBank } \\
\text { accession number }\end{array}$} & \multirow[t]{2}{*}{ Class } & \multirow[t]{2}{*}{ Genotype } & \multicolumn{5}{|c|}{$\begin{array}{l}\text { Consensus amino acids and its position } \\
\text { in the fusion protein }\end{array}$} \\
\hline & & & ${ }^{2} \mathrm{D}$ & ${ }^{93} \mathrm{~A}$ & ${ }^{104} \mathrm{E}$ & ${ }^{337} \mathrm{Y}$ & ${ }^{489} \mathrm{D}$ \\
\hline AB524405 & I & 1 & . & . & . & . & . \\
\hline JF893453 & I & 2 & . & . & . & . & . \\
\hline FJ597594 & I & 3 & . & . & . & . & . \\
\hline FJ597597 & I & 3 & . & . & . & . & . \\
\hline EF564825 & I & 4 & . & . & . & . & . \\
\hline AY626267 & I & 5 & . & . & . & . & . \\
\hline AY626266 & I & 6 & . & . & . & . & . \\
\hline EF564819 & I & 7 & . & . & . & . & . \\
\hline EF564815 & I & 8 & . & . & . & . & . \\
\hline AB858995-9002 & I & 3 & $\mathrm{~N}$ & $\mathrm{~T}$ & D & $\mathrm{H}$ & $\mathrm{N}$ \\
\hline NC 005036 & II & VII & G & $\mathrm{T}$ & G & . & E \\
\hline FJ597609 & II & $\mathrm{Ib}$ & G & $\mathrm{T}$ & . & . & . \\
\hline DQ195265 & II & IV & G & $\mathrm{T}$ & . & . & . \\
\hline
\end{tabular}

Amino acids that match the consensus exactly are denoted by '.'

Table 4. Specific amino acids substitution for HN protein in this study

\begin{tabular}{|c|c|c|c|c|c|c|c|c|c|c|c|c|c|c|c|c|c|c|c|}
\hline \multirow{2}{*}{$\begin{array}{c}\text { GenBank } \\
\text { accession number }\end{array}$} & \multicolumn{19}{|c|}{ Consensus amino acids and its position in the HN protein of Class I genotype 3} \\
\hline & ${ }^{7} \mathrm{Q}$ & ${ }^{43} \mathrm{~A}$ & ${ }^{52} \mathrm{~T}$ & ${ }^{60} \mathrm{P} / \mathrm{T}$ & ${ }^{61} \mathrm{~V}$ & ${ }^{178} \mathrm{~F}$ & ${ }^{248} \mathrm{D}$ & ${ }^{261} \mathrm{D}$ & ${ }^{293} \mathrm{G}$ & ${ }^{308} \mathrm{I}$ & ${ }^{311} \mathrm{R}$ & ${ }^{381} \mathrm{~T}$ & ${ }^{396} \mathrm{~T}$ & ${ }^{422} \mathrm{~S}$ & ${ }^{423} \mathrm{P}$ & ${ }^{567} \mathrm{R} / \mathrm{Q}$ & ${ }^{577} \mathrm{~A}$ & ${ }^{580} \mathrm{~T}$ & ${ }^{590} \mathrm{~V}$ \\
\hline AB859003 & . & $\mathrm{T}$ & . & S & . & . & . & . & . & & . & . & . & . & . & . & $\mathrm{S}$ & . & . \\
\hline AB859005 & E & $\mathrm{T}$ & S & $\mathrm{S}$ & E & . & $\mathrm{H}$ & . & . & . & . & . & . & $\mathrm{C}$ & . & . & $\mathrm{S}$ & . & . \\
\hline AB859006 & . & $\mathrm{T}$ & . & $\mathrm{S}$ & . & . & . & . & . & $\mathrm{K}$ & . & . & . & . & . & . & S & . & . \\
\hline AB859007 & . & $\mathrm{T}$ & . & S & . & . & . & . & . & . & . & . & . & . & . & . & S & . & . \\
\hline AB859004 & . & $\mathrm{T}$ & . & $\mathrm{S}$ & . & . & . & . & . & . & $\mathrm{P}$ & . & . & . & . & . & S & . & . \\
\hline AB859009 & . & $\mathrm{T}$ & . & S & . & $\mathrm{L}$ & . & $\mathrm{H}$ & . & . & . & S & . & . & . & . & S & . & . \\
\hline $\begin{array}{l}\text { AB859010 } \\
\text { (chicken strain) }\end{array}$ & . & $\mathrm{T}$ & . & $\mathrm{S}$ & . & . & . & . & $\mathrm{E}$ & . & . & . & $\mathrm{N}$ & . & A & W & $\mathrm{S}$ & I & I \\
\hline $\begin{array}{l}\text { AB859008 } \\
\text { (chicken strain) }\end{array}$ & . & $\mathrm{T}$ & . & $\mathrm{S}$ & . & . & . & . & E & . & . & . & . & . & . & & $\mathrm{S}$ & I & I \\
\hline
\end{tabular}

Amino acids that match the consensus exactly are denoted by '.'

differed from other class I viruses (genotypes 1 to 9 , presented in Table 1) by 3.3 to $10.8 \%$, whereas the isolates differed from class II (presented in Table 1) viruses by 22.7 to $33.2 \%$. The HN coding regions of the 8 isolates were 1,851 nt in length and encoded a protein product consisting of 617 amino acids. The amino acid identities for the HN regions from the isolates were compared to other class I genotype 3 viruses (presented in Table 1), and the isolates differed from the other viruses by 0.9 to $7.3 \%$.

To estimate the risk of the viruses pose to poultry populations, it is essential to evaluate the evolution of these viruses.
Prior to phylogenetic analysis, ClustalX 2.0 [19] and Lasergene V 7.1 software packages were used for sequences analysis. MEGA 5.0 software was used for phylogenetic analysis using a neighbor-joining method with 1,000 bootstrap replicates [28]. The strains of F gene are shown in Table 1. Phylogenetic analyses using the 1,662-bp region of the $\mathrm{F}$ gene and the 2001-bp region of the $\mathrm{HN}$ gene sequence indicate that all eight NDV strains form a distinct cluster within the genotype 3 viruses and are most closely related to Chinese poultry isolates. A phylogenetic analysis of $\mathrm{F}$ gene revealed that the isolated strains were highly identical and were more species 


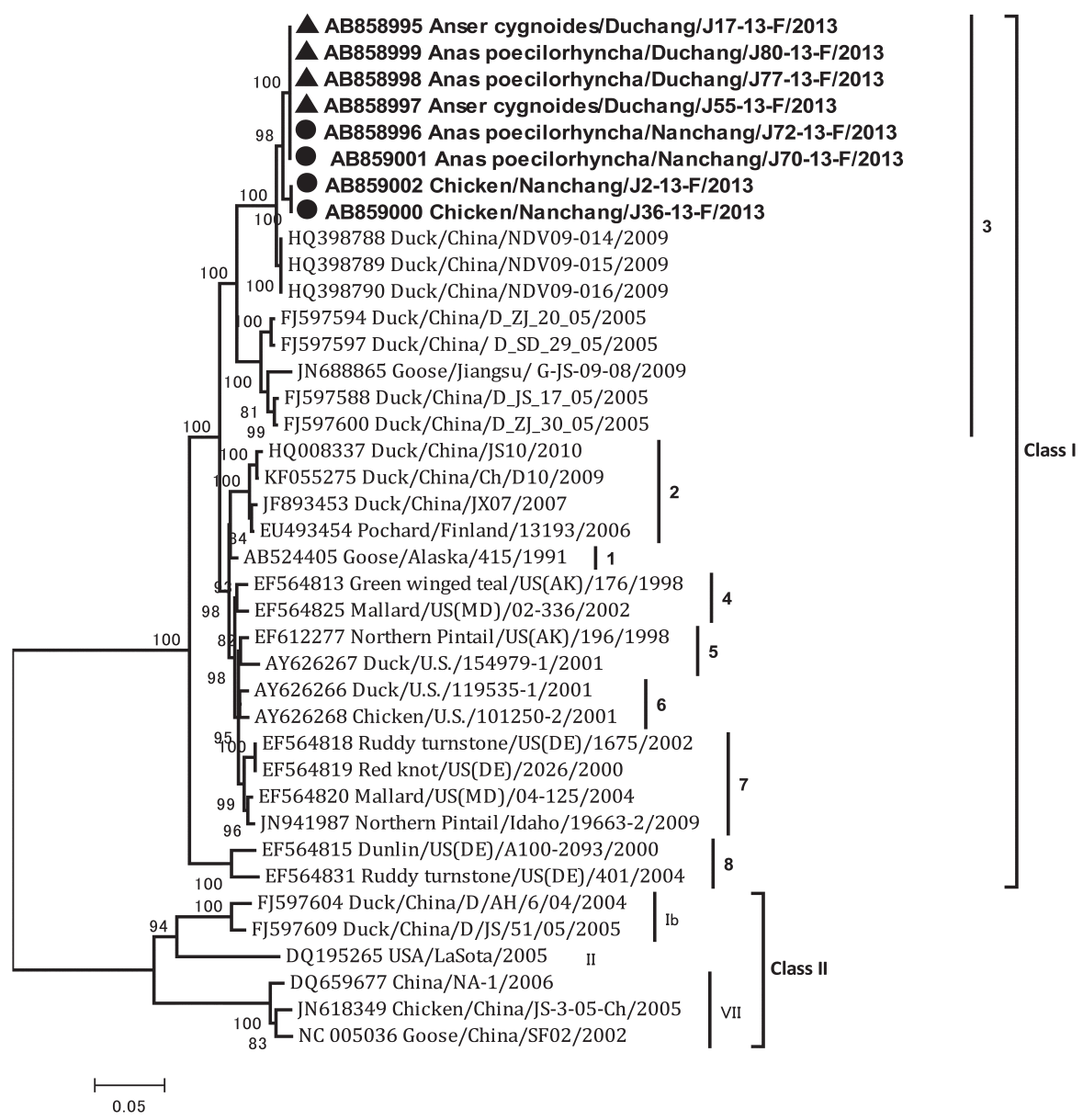

Fig. 2. Phylogenetic analysis of the nucleotide sequences of the NDV F gene (nt 1-1,662). The sequences in our study are indicated by circles (Nanchang strains) and triangles (Duchang strains). Bootstrap values (based on 1,000 replicates) for each node are provided if $>75 \%$ of the values were available.

specific (chicken and waterfowl) than site specific (Nanchang and Duchang regions). Two branches radiate out from class I genotype 3 (Fig. 2). The first branch contains poultry viruses, all of which originated in eastern China and were isolated between $2005(\mathrm{D} / \mathrm{ZJ} / 20 / 05, \mathrm{D} / \mathrm{SD} / 29 / 05, \mathrm{D} / \mathrm{JS} / 17 / 05$ and $\mathrm{D} /$ $\mathrm{ZJ} / 30 / 05$ ) and 2009 (G-JS-09-08). The other cluster includes viruses associated with poultry viruses isolated in eastern China in 2009 (NDV09-014, NDV09-015 and NDV09-016) and isolated from Anas poecilorhyncha, Anser cygnoides, and chickens in our study. Anas poecilorhyncha and Anser cygnoides are found in most freshwater habitats, which are widespread throughout China. This finding indicates that class I genotype 3 viruses have also emerged in the wild bird and poultry population in China. A phylogenetic comparison of HN gene sequences from all eight NDV isolates and 11 reference NDVs from GenBank (all class I genotype 3) demonstrated that the $8 \mathrm{NDV}$ strains form a distinct cluster within the genotype 3 viruses and are different from strains isolated between 2009 and 2010 (Fig. 3).

Most poultry in the Poyang Lake region are raised in a free-range style. This raises the possibility that migratory birds could introduce viruses into the local resident wild bird population, which could then distribute the virus to local domestic birds. Migratory wild birds have been shown to transmit NDVs to free-range poultry through direct contact or through the contamination of water or feed sources [29]. In our study, 2 NDVs isolated from chickens indicate that domestic poultry would shed these lentogenic viruses, which may be prevalent in local poultry populations. The close phylogenetic proximity of these isolates indicates that viral transmission may occur between poultry and wild birds. Efforts are needed to restrict the interactions between wild birds and poultry, as these 2 hosts appear to be subject to continuing exchange of NDV strains [20].

Since the discovery of NDV in 1926 , ND has been regarded as endemic to many countries. Vaccination has been widely used for many years to prevent and control ND in China, but this disease is still sporadic and is a fatal viral disease for poultry industry [25]. Most NDV research has been performed on virulent isolates, and very little is known about 


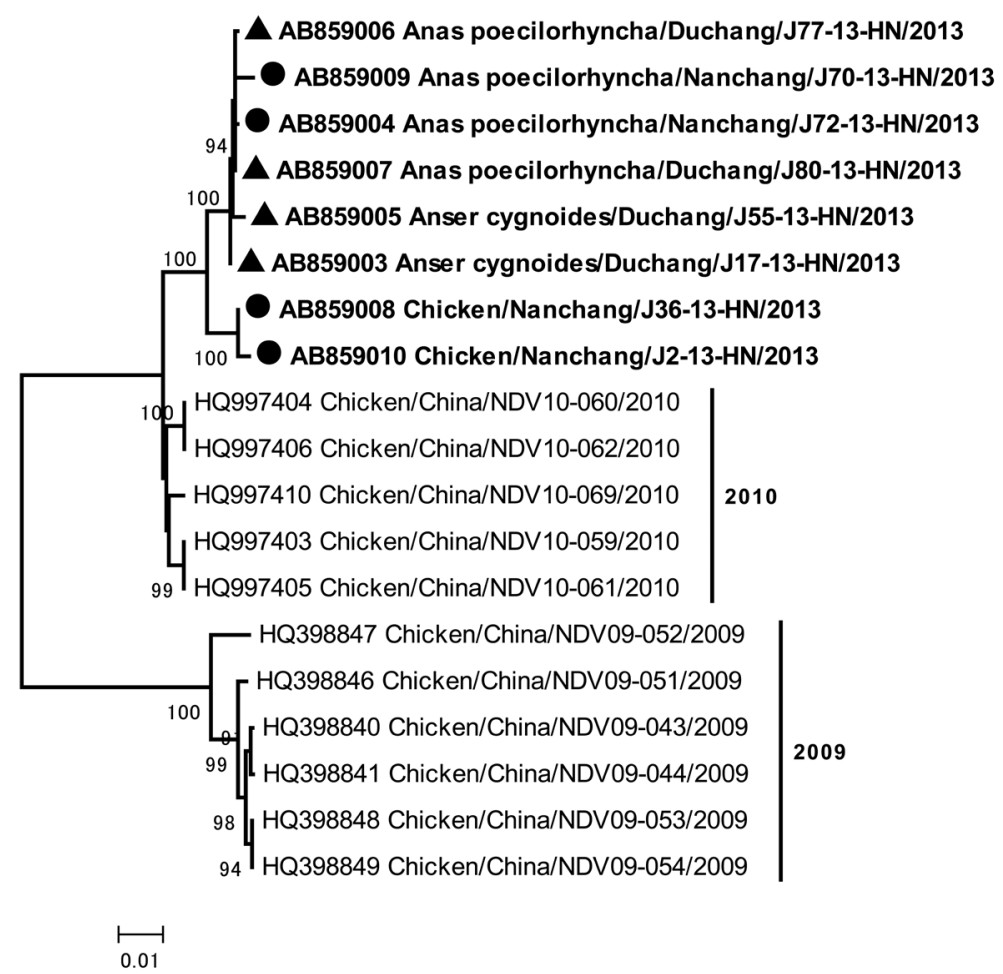

Fig. 3. Phylogenetic analysis of the nucleotide sequences of class I genotype $3 \mathrm{HN}$ gene sequences (nt 1-2,001). The sequences in our study are indicated by circles (Nanchang strains) and triangles (Duchang strains). Bootstrap values (based on 1,000 replicates) for each node are provided if $>75 \%$ of the values were available.

the evolution of lentogenic NDVs [23]. Wild aquatic birds are the natural reservoirs of NDV, and they generally harbor lentogenic strains [15], but lentogenic strains have also been detected in poultry vaccinated with live virus. However, lentogenic viruses would have the potential to increase their virulence long time or from one host to another [2, 27]. The MDT values of strains isolated from chickens are lower than those of strains isolated from wild birds. In addition, 3 residue substitutions were found in the HN protein sequences of strains isolated from chickens compared to strains isolated from wild birds. These results indicated that the MDT values and the mutation of the NDVs are related to the host. Moreover, the new host environment may play a selective forces role in the acquisition of virulence [30]. In Australia, endemic lentogenic viruses have been circulating in domestic poultry for more than 30 years, but unknown conditions have since caused these NDVs to undergo genomic changes, resulting in a more virulent genotype [13]. These results indicate that lentogenic poultry strains may exist in nature through waterfowl-to-domestic poultry transmission.

GenBank accession numbers: All the sequences $(n=16)$ used in this study were submitted to GenBank with $\mathrm{F}$ gene accession numbers (AB858995-AB859002) and HN gene accession numbers (AB859003-AB859010).

ACKNOWLEDGMENTS. This work was supported by the National Key Technologies R\&D Program (No.2013BAD12B04) and the Emergency Research Project on human infection with avian influenza H7N9 virus from the National Ministry of Science and Technology (No. KJYJ2013-01-01 to Dr. Gao)

\section{REFERENCES}

1. Alexander, D. J. 2000. Newcastle disease and other avian paramyxoviruses. Rev. Sci. Tech. 19: 443-462. [Medline]

2. Alexander, D. J. and Parsons, G. 1986. Protection of chickens against challenge with the variant virus responsible for Newcastle disease in 1984 by conventional vaccination. Vet. Rec. 118: 176-177. [Medline] [CrossRef]

3. Cai, S., Li, J., Wong, M. T., Jiao, P., Fan, H., Liu, D., Liao, M., Jiang, J., Shi, M. and Lam, T. T. 2011. Genetic characterization and evolutionary analysis of 4 Newcastle disease virus isolate full genomes from waterbirds in South China during 2003-2007. Vet. Microbiol. 152: 46-54. [Medline] [CrossRef]

4. Chambers, P., Millar, N. S., Bingham, R. W. and Emmerson, P. T. 1986. Molecular cloning of complementary DNA to Newcastle disease virus, and nucleotide sequence analysis of the junction between the genes encoding the haemagglutinin-neuraminidase and the large protein. J. Gen. Virol. 67: 475-486. [Medline] [CrossRef]

5. Czeglédi, A., Ujvari, D., Somogyi, E., Wehmann, E., Werner, O. and Lomniczi, B. 2006. Third genome size category of avian paramyxovirus serotype 1 (Newcastle disease virus) and evolu- 
tionary implications. Virus Res. 120: 36-48. [Medline] [CrossRef]

6. de Leeuw, O. and Peeters, B. 1999. Complete nucleotide sequence of Newcastle disease virus: evidence for the existence of a new genus within the subfamily Paramyxovirinae. J. Gen. Virol. 80: 131-136. [Medline]

7. de Leeuw, O. S., Koch, G., Hartog, L., Ravenshorst, N. and Peeters, B. P. 2005. Virulence of Newcastle disease virus is determined by the cleavage site of the fusion protein and by both the stem region and globular head of the haemagglutininneuraminidase protein. J. Gen. Virol. 86: 1759-1769. [Medline] [CrossRef]

8. Diel, D. G., da Silva, L. H., Liu, H., Wang, Z., Miller, P. J. and Afonso, C. L. 2012. Genetic diversity of avian paramyxovirus type 1: proposal for a unified nomenclature and classification system of Newcastle disease virus genotypes. Infect. Genet. Evol. 12: 1770-1779. [Medline] [CrossRef]

9. Dortmans, J. C., Peeters, B. P. and Koch, G. 2012. Newcastle disease virus outbreaks: vaccine mismatch or inadequate application? Vet. Microbiol. 160: 17-22. [Medline] [CrossRef]

10. Fan, S., Sun, H., Ying, Y., Gao, X., Wang, Z., Yu, Y., Li, Y., Wang, T., Yu, Z. and Yang, S. 2013. Identification and characterization of porcine kobuvirus variant isolated from suckling piglet in Gansu province, China. Viruses 5: 2548-2560. [Medline] [CrossRef]

11. Glickman, R. L., Syddall, R. J., Iorio, R. M., Sheehan, J. P. and Bratt, M. A. 1988. Quantitative basic residue requirements in the cleavage-activation site of the fusion glycoprotein as a determinant of virulence for Newcastle disease virus. J. Virol. 62: 354-356. [Medline]

12. Gould, A. R., Hansson, E., Selleck, K., Kattenbelt, J. A., Mackenzie, M. and Della-Porta, A. J. 2003. Newcastle disease virus fusion and haemagglutinin-neuraminidase gene motifs as markers for viral lineage. Avian Pathol. 32: 361-373. [Medline] [CrossRef]

13. Gould, A. R., Kattenbelt, J. A., Selleck, P., Hansson, E., DellaPorta, A. and Westbury, H. A. 2001. Virulent Newcastle disease in Australia: molecular epidemiological analysis of viruses isolated prior to and during the outbreaks of 1998-2000. Virus Res. 77: 51-60. [Medline] [CrossRef]

14. Gravendyck, M., Ammermann, P., Marschang, R. E. and Kaleta, E. F. 1998. Paramyxoviral and reoviral infections of iguanas on Honduran Islands. J. Wildl. Dis. 34: 33-38. [Medline] [CrossRef]

15. Hu, B., Huang, Y., He, Y., Xu, C., Lu, X., Zhang, W., Meng, B., Yan, S. and Zhang, X. 2010. Avian influenza virus and Newcastle disease virus (NDV) surveillance in commercial breeding farm in China and the characterization of Class I NDV isolates. Vet. Microbiol. 144: 82-86. [Medline] [CrossRef]

16. Jindal, N., Chander, Y., Chockalingam, A. K., de Abin, M., Redig, P. T. and Goyal, S. M. 2009. Phylogenetic analysis of Newcastle disease viruses isolated from waterfowl in the upper midwest region of the United States. Virol. J. 6: 191. [Medline] [CrossRef]

17. Kattenbelt, J. A., Stevens, M. P. and Gould, A. R. 2006. Sequence variation in the Newcastle disease virus genome. Virus Res. 116: 168-184. [Medline] [CrossRef]

18. Kim, L. M., King, D. J., Curry, P. E., Suarez, D. L., Swayne, D. E., Stallknecht, D. E., Slemons, R. D., Pedersen, J. C., Senne,
D. A. and Winker, K. 2007. Phylogenetic diversity among low-virulence newcastle disease viruses from waterfowl and shorebirds and comparison of genotype distributions to those of poultry-origin isolates. J. Virol. 81: 12641-12653. [Medline] [CrossRef]

19. Larkin, E. K., Morris, N. J., Li, Y., Nock, N. L. and Stein, C. M. 2007. Comparison of affected sibling-pair linkage methods to identify gene $\mathrm{x}$ gene interaction in GAW15 simulated data. BMC. Proc. 1 Suppl. 1: S66. [Medline] [CrossRef]

20. Lindh, E., Ek-Kommonen, C., Vaananen, V. M., Alasaari, J., Vaheri, A., Vapalahti, O. and Huovilainen, A. 2012. Molecular epidemiology of outbreak-associated and wild-waterfowl-derived newcastle disease virus strains in Finland, including a novel class I genotype. J. Clin. Microbiol. 50: 3664-3673. [Medline] [CrossRef]

21. Liu, H., Wang, Z., Wang, Y., Sun, C., Zheng, D. and Wu, Y. 2008. Characterization of Newcastle disease virus isolated from waterfowl in China. Avian Dis. 52: 150-155. [Medline] [CrossRef]

22. Maminiaina, O. F., Gil, P., Briand, F. X., Albina, E., Keita, D., Andriamanivo, H. R., Chevalier, V., Lancelot, R., Martinez, D. and Rakotondravao, R. 2010. Newcastle disease virus in Madagascar: identification of an original genotype possibly deriving from a died out ancestor of genotype IV. PLOS ONE 5: e13987. [Medline] [CrossRef]

23. Miller, P. J., Decanini, E. L. and Afonso, C. L. 2010. Newcastle disease: evolution of genotypes and the related diagnostic challenges. Infect. Genet. Evol. 10: 26-35. [Medline] [CrossRef]

24. Miller, P. J., Kim, L. M., Ip, H. S. and Afonso, C. L. 2009. Evolutionary dynamics of Newcastle disease virus. Virology 391: 64-72. [Medline] [CrossRef]

25. Rui, Z., Juan, P., Jingliang, S., Jixun, Z., Xiaoting, W., Shouping, Z., Xiaojiao, L. and Guozhong, Z. 2010. Phylogenetic characterization of Newcastle disease virus isolated in the mainland of China during 2001-2009. Vet. Microbiol. 141: 246-257. [Medline] [CrossRef]

26. Seal, B. S., King, D. J. and Bennett, J. D. 1995. Characterization of Newcastle disease virus isolates by reverse transcription PCR coupled to direct nucleotide sequencing and development of sequence database for pathotype prediction and molecular epidemiological analysis. J. Clin. Microbiol. 33: 2624-2630. [Medline]

27. Shengqing, Y., Kishida, N., Ito, H., Kida, H., Otsuki, K., Kawaoka, Y. and Ito, T. 2002. Generation of velogenic Newcastle disease viruses from a nonpathogenic waterfowl isolate by passaging in chickens. Virology 301: 206-211. [Medline] [CrossRef]

28. Tamura, K., Peterson, D., Peterson, N., Stecher, G., Nei, M. and Kumar, S. 2011. MEGA5: molecular evolutionary genetics analysis using maximum likelihood, evolutionary distance, and maximum parsimony methods. Mol. Biol. Evol. 28: 2731-2739. [Medline] [CrossRef]

29. Warke, A., Appleby, L. and Mundt, E. 2008. Prevalence of antibodies to different avian paramyxoviruses in commercial poultry in the United States. Avian Dis. 52: 694-697. [Medline] [CrossRef]

30. Zanetti, F., Berinstein, A. and Carrillo, E. 2008. Effect of host selective pressure on Newcastle disease virus virulence. Microb. Pathog. 44: 135-140. [Medline] [CrossRef] 